\title{
Reputation, Credibility and Monetary Policy Effectiveness
}

\author{
- Gabriel Caldas Montes*
}

\begin{abstract}
RESUMO
Como reputação e credibilidade são importantes elementos para a eficácia da política monetária, o trabalho explora os conceitos de ambos e suas importâncias em um contexto em que as políticas dos bancos centrais não são neutras, sendo capazes de afetar variáveis reais e nominais. $O$ trabalho busca contribuir com uma nova análise de como o tipo de reputação desenvolvido pela autoridade monetária afeta o estado de expectativas e, assim, o desempenho econômico, possibilitando um caso particular que chamaremos de "armadilha de credibilidade" - a qual torna a política monetária ineficaz em afetar a atividade econômica real quando necessário. Embora a abordagem proposta pelo trabalho apresente algumas similaridades com a abordagem ortodoxa acerca da importância da reputação e da credibilidade para os bancos centrais e suas políticas, a abordagem distingue-se da ortodoxa em termos de recomendações de política monetária e do tipo de reputação que deve ser desenvolvida.
\end{abstract}

\section{Palavras-Chave}

reputação, credibilidade, política monetária, inflação, crescimento econômico

\begin{abstract}
As reputation and credibility are important elements for monetary policy effectiveness, the paper aims at exploring the concepts of both and its importance in a context where central banks policies are not neutral, that is, monetary policy affects real and nominal variables. The paper seeks to contribute with a new analysis of how the sort of reputation developed by the monetary authority affects the state of expectations, and then the economic performance, enabling a particular situation that we call "credibility trap" - which makes monetary policy ineffective to affect real activity when necessary. Although the paper presents some similarities to the orthodox approach regarding both reputation and credibility's importance for central banks and its policies, it is different from the orthodox approach speaking of distinct forms of monetary policy recommendations and the sort of reputation that it recommends to be developed.
\end{abstract}

\section{KEYWORDS}

reputation, credibility, monetary policy, inflation, economic growth

\section{JEL ClassificATION}

$E / 2, E 40, E 52, E 58$

\footnotetext{
* Professor da Universidade Federal Fluminense. Endereço para contato: Rua Tiradentes, 17 - Ingá - Niterói - RJ. CEP: 24.210-5 I0. E-mail: gabrielmontesuff@yahoo.com.br.

(Recebido em janeiro de 2008. Aceito para publicação em julho de 2008).
} 
Until the beginning of the 1970s orthodox Keynesianism occupied the mainstream position at economics and monetary policy was understood as a sort of economic policy that should be used to keep output and employment at high levels. However, in the mid-1980s - with the New Classical (rational expectations) revolution - it is perceived a clear change of paradigm in terms of monetary policy conduction with the establishment of a new consensus, where price stability became the main objective for the monetary authority.

Theoretical analyses regarding the conduction of monetary policy have suffered radical changes since the concept of rational expectations was embodied into economic theory. Several natural rate models that have appeared in the macroeconomic literature - based on the works of Muth (1961), Lucas (1972a, 1972b, 1973), Sargent (1973) and Sargent and Wallace $(1975,1981)$ - shared the idea that in the absence of informational barriers and money illusion monetary policy should not be used to affect real output and employment, but to keep inflation under control.

The combination and acceptance of the following assumptions, (i) rational expectations, (ii) a continuous market-clearing equilibrium economy (with fully flexible prices), and (iii) the profit-utility maximizing behavior, bring forth several important conclusions about economic policy implications. Among these implications we can identify: the monetary policy inefficacy to affect output and employment at short and long terms; the disinflation costs that fall on real activity; the time-inconsistency problem from optimal discretionary policies; the importance of reputation and credibility for the monetary authority and its policies, respectively, and; the development of "commitment technologies" and rules ${ }^{1}$ that restrict monetary policy and attempt to avoid the inflationary bias and the time-inconsistency problem.

As New Classical economics has advanced significantly, some developments in monetary theory have emphasized the role and importance of the central banks' reputation and the credibility of their policies for the conduction of monetary policy and the observed outcomes at the economy (KYDLAND; PRESCOTT, 1977; BARRO; GORDON, 1983a, 1983b; BACKUS; DRIFFILL, 1985a, 1985b; BLANCHARD, 1985; CUKIERMAN, 1985; BARRO, 1986; CUKIERMAN; MELTZER, 1986; ROGOFF, 1987; ANDERSEN, 1989; BLACKBURN; CHRISTENSEN, 1989;

l A considerable number of solutions for the time-inconsistency problem - that is, how a policy announcement can be made credible, so that private agents expect it to be carried out - were developed and presented during the last two decades. These included, for instance, institutional and legal constraints, delegation of decisions, contractual arrangements and monetary policy rules (see for example the works of ROGOFF, 1985; CUKIERMAN, 1992; DEBELLE; FISCHER, 1994; LOHMANN, 1992; PERSSON; TABELLINI, 1994; WALSH, 1995; SVENSSON, 1997; TAYLOR, 1993). 
DRAZEN, 2000). While new models regarding credibility and reputation have incorporated New Classical assumptions within their frameworks leading, at the same time, the acquired results to become compatible with the notion of monetary policy neutrality, they also strengthened the idea that monetary policy will be more effective if the goals followed by central banks are considered credible by the public and if the policy is implemented by central banks with a strong reputation of being an institution mainly worried with price stability.

The theoretical foundation that explains the development of works concerned with reputation and credibility of central banks and their policies is based on the "rules rather than discretion" literature. The arguments regarding the monetary policy's credibility and the central banks' reputation were presented for the first time by Fellner (1976, 1979) and by Kydland and Prescott (1977) - for the case of credibility - and, later, by Barro and Gordon (1983a, 1983b) - for the case of reputation - when they analyzed economies presenting high and undesirable inflation rates. Both works of Kydland and Prescott and Barro and Gordon attempted to prove that credibility and reputation represent key-elements for the solution of the inflationary bias and the time-inconsistency problems.

Credibility and reputation are, in essence, distinct concepts. While credibility is associated with the degree of confidence that the public has on central bank's ability and determination to keep itself on an announced goal and to achieve it, that is, if the policies (or plans) are credible, reputation is related to the public's belief about the preferences of the policymaker and to the expectations formed by the public about the actions that monetary authorities will take.

Recent developments in macroeconomics (such as GOODFRIEND; KING, 1997; KING, 2000; ROMER, 2000; TAYLOR, 1993, 2000; GOODFRIEND, 2004; WOODFORD, 2003) points out that monetary policies will be more effective and then will conquer credibility if central banks strengthen their reputation and follow a rule concerned with inflation stability (which should be, according to them, the main and only central bank's goal). ${ }^{2}$

Theoretically speaking, there is not consensus about the effects provoked by monetary policies over the economy (either at the short or the long terms), although there is agreement about the four main final objectives pursued - together or individually

2 These developments are fundamentally based on the following assumptions: rational expectations hypothesis; money neutrality in the long run (little or no long run trade off between inflation and real activity); supply-side equilibrium determined (aggregate demand management is irrelevant in determining real equilibrium levels); inflation process explained by demand pressures (excess of aggregate demand is the main source of inflation); credibility plays an important role in understanding the effects of the monetary policy. 
- by governments and policymakers: low and stable inflation, sustainable economic growth, low unemployment rate and stability of the financial system.

Nevertheless, there is wide consensus among central bankers and academics about some basic principles that must serve as useful guides for central banks conduct their policies and better reach their goals. These principles, as suggested by Mishkin (2000), are: 1) price stability provides substantial benefits; 2) fiscal policy should be aligned with monetary policy; 3) time-inconsistency is a problem to be avoided; 4) monetary policy should be forward-looking; 5 ) accountability is a basic principle of democracy; 6) monetary policy should be concerned about output as well as price fluctuations, and; 7) the most serious economic downturns are associated with financial instability. Another important and basic principle that may be added to that list is: in modern economies monetary policy works through real interest rates and expectations.

On the other hand, dealing with the concepts of monetary economy, effective demand and liquidity preference (KEYNES, 1936, 1973) it is opened the possibility for output and employment improvement as well as inflation stability become - once more - goals for central banks. Thus, the developments concerning the influence of reputation and credibility over the economy must be enlarged enabling the exploration of a new approach which considers that monetary policies are not neutral. The role of central bankers' reputation and the credibility of their policies must be replaced since both exert influence over the expectations of the public, causing changes in aggregate demand. The ability of central banks to affect the actual and future economic performances through public decisions depends on their ability to influence private sector expectations regarding not only the future path of the interest rate and the future state of the economy but also the manner in which they implement actual and future policies, make their announcements and account to the public.

Considering the arguments above, the paper aims at exploring the concepts of reputation and credibility and their importance in a context where central banks' policies are not neutral, that is, monetary policies affect real and nominal variables. The paper seeks to contribute with a new analysis of how the sort of reputation developed by the monetary authority and the commitment to a mechanical rule (that is, a strict rule-based policy) affect the state of expectations, and then the economic performance, enabling a particular situation that we call "credibility trap" - which makes monetary policy ineffective to affect real activity when necessary. Although the approach suggested on the paper presents some similarities with the orthodox approach regarding both reputation and credibility's importance for central banks and its policies, it is different from the orthodox approach speaking of distinct forms of monetary policy recommendations. 
Besides this introduction, the article is divided into three sections. The second briefly presents the New Classical orthodox approach for credibility and reputation based on the time-inconsistency literature and the following developments on the "rules rather than discretion" debate. The third section develops an alternative approach regarding the role of central banks' reputation and the credibility of their policies and also presents a new concept called "credibility trap" based on the sort of reputation suggested by the New Classical approach. Finally, the fourth section presents the final considerations, emphasizing the importance of reputation and credibility for both approaches and the fact that these approaches differ from each other in terms of monetary policy recommendations and results for the economy.

\section{THE MEANING AND IMPORTANCE OF CREDIBILITY AND REPUTA- TION: THE NEW CLASSICAL TIME-INCONSISTENCY APPROACH}

At the same time that macroeconomic theory suffered radical transformations, leaded by the revolution of rational expectations, a new discussion emerged from the following problem: how social losses should be minimized when actions of economic policy must be taken at several periods of time. At the end of the 1970s, the work of Kydland and Prescott (1977) began the study about monetary policy credibility, with emphasis at the time-inconsistency problem. It provided - as did Friedman $(1968,1969)$ - a reformulation of the case against discretionary policies through a New Classical model which argued that there is no way to optimal control theory become applicable to economic planning when expectations are rational.

The fundamental insight regarding the notion of time-inconsistency and credibility, presented by Kydland and Prescott (1977), is that when economic agents are forward-looking the policy problem emerges as a dynamic game between the government and the private sector - where the government is the dominant player and the private sector is the follower. Let's suppose the following situation to understand the time-inconsistency problem: the government formulates what it considers to be an optimal policy and then announces its intentions to the private sector; if this policy is believed, then in the next periods, it may not remain optimal, since the government finds that it has an incentive to renege on its previously announced optimal policy. In this sense, an optimal policy suggested at time $t$ is time-inconsistent if reoptimization at $t+n$ implies a different optimal policy, consequently, timeinconsistent policies will significantly weaken the credibility of future announced policies. $^{3}$

3 According to Barro and Gordon (1983a), the term "time-inconsistent" refers to the policymaker's incentives to deviate from an announced policy when private agents expect it to be followed. This is a significant problem of decision-making in democracies since preferences may change over time. It 
The New Classical approach argues that since the monetary authority has no precommitment with an announced policy and usually makes use of its discretionary powers, it will have an incentive to cheat, making the announced policy time-inconsistent and then non-credible. The approach defends that discretionary policies produce sub-optimal outcomes since exhibit an inflationary bias. In this sense, a considered optimal policy which begins to lose credibility due to time inconsistency increases its chances to become neither feasible nor optimal.

The orthodox approach about credibility - an extension of the New Classical theory - supports the idea that the economic system is eminently stable and so active policies are, beyond useless, harmful. Besides, it suggests that monetary policies would only be effective if unexpected and, hence, policymakers would have an incentive to cheat so as to promote output increases (even if transitory). However, once private agents' expectations about inflation are corrected, unemployment would lean to return to its natural rate, though with a higher equilibrium inflation rate. It means that optimizing actions implemented by a monetary authority with discretionary powers tend to carry the economy to suboptimal equilibriums, with higher levels of inflation.

One might conclude that the possibility of changing exogenously the monetary supply, attempting to make unemployment lower than its natural rate, leads to losses of monetary policy credibility since agents recognize the incentive to promote unexpected expansions. Therefore, credibility improvements are unequivocally related to the expectation that monetary policy is not going to change - that is, the monetary authority will follow its announcements - and will be implemented based on mechanisms that make discretionary actions impossible.

The work of Blackburn and Christensen (1989, p. 2) points out that "the concept of credibility is not well defined in economics and has received different interpretations by different authors. Perhaps the most general interpretation is the extent to which beliefs about the current and future course of economic policy are consistent with the program originally announced by policy makers". Drazen (2000, p. 166) presents two distinct concepts about credibility: the credibility of the policymaker and the credibility of the policy. The former means that "the policymaker will attempt to do exactly what he says", while the latter "could be thought of as the expectation that policy will be carried out".

As the New Classical economics suggests, for a monetary policy being considered credible it must follow a rule in which the agents will believe that the monetary

means that "a conflict of interests of some sort is necessary for time inconsistency in police to arise" (DRAZEN, 2000, p. 102). In this sense, "time consistency, like all other problems of political economy, arises because of heterogeneity leading to conflict of interests" (DRAZEN, 2000, p. 130). 
authority is not going to renege. Hence, to affirm that a policy is credible it is necessary that the public believes on the rule and, through expectations, on the results the monetary authority is attempting to reach. As expectations are considered an important monetary transmission element, the lack of credibility of a certain policy may complicate, or even impede, the reach of a certain goal due to formed expectations.

Whether a policy is credible or not, it will depend: (i) on the expectations formed by the public about its effects on the economy, (ii) on the policymaker's credibility and reputation and (iii) on the circumstances the policymaker is going to face. A policy may be feasible in one set of circumstances, but not in others, that is, "expectations of how external environment will develop, rather than the credibility of the policymaker, will then be crucial in assessing whether the policy is credible" (DRAZEN, 2000, p. 167).

A credible monetary policy, following the New Classical thought, must present the following features: (i) is implemented by an independent central bank through a rule which bounds the monetary authority's actions, avoiding the time-inconsistency problem and the inflation bias; (ii) seeks to keep inflation under control considering that output and employment will be at their natural rates at the long term; (iii) converges the expectations of the public to its goal, and consequently, makes the public believe that the implemented policy will be carried out and the goal will be reached as fast as possible, and; (iv) decreases the costs of disinflation in the short run whenever a policy against inflation must be implemented.

In order to enhance the credibility of its policies and to affect the expectations of the public, central banks will attempt to establish a specific sort of reputation. The concept of reputation can be thought in terms of the actions an agent is expected to take. "Reputation often refers to generally held beliefs about an individual's (or a group's) character or characteristics" (DRAZEN, 2000, p. 168). According to the reputation built by central banks, the public form expectations about the policymakers' future actions. For instance, as the monetary authority's reputation of being tough on inflation becomes stronger, it strengthens the confidence on expectations regarding future monetary authority's actions seeking to establish and maintain a stable price environment. This is the sort of reputation that the New Classical economics suggests to central banks; an institution that must attempt to build the reputation of being tough on inflation. According to this approach, the monetary policy credibility depends on the expectations that the public form for monetary authorities' future actions against inflation.

Agents are often concerned about central banks' behavior because it demonstrates their character or characteristics. Since the public attempts to foresee central banks' 
future behaviors based on what it has observed on the past - and, of course, making use of all available information - it is important to perceive that reputation plays a fundamental role for that, because it reflects some sort of repeated action (or behavior) that policymakers have always presented.

The work of Barro and Gordon (1983b) was the first to build a game model to analyze policymakers' reputation. Backus and Driffill (1985a) extended the work of Barro \& Gordon to a finite-time horizon model $^{4}$ in which the public is uncertain about the preferences of the policymaker. The subsequent models inspired in the works of Kydland and Prescott (1977) and Barro and Gordon (1983a, 1983b) suggests that there is no shortcut to gain credibility and make reputation stronger; both must be built and nurtured over time. The New Classical economics regards that central banks can best improve their credibility and reputation by keeping a consistent record of inflation within the target, and by not yielding to pressure for short-term gains in economic growth at the expense of long term price stability. Moreover, the monetary policy should be conducted by a strict rule that makes the public's expectations about policymakers' future actions compatible with the reputation of being an institution tough on inflation.

It is true that credibility and reputation can considerably improve the effectiveness of monetary policies since they increase the confidence of the agents on expectations regarding future central banks' actions. Policy signals from credible monetary authorities - with strong and well defined reputations - will be better understood and generally accepted by market participants and the public, resulting in a more effective monetary transmission mechanism (through expectations) and a lower cost of disinflation whenever a policy of this sort might be implemented.

The New Classical models support the use of the Phillips curve as a framework to describe the trade off between unemployment (output) and inflation whenever unexpected monetary policies were implemented. As these models make use of rational expectations, the inexistence of the trade off is accepted at the long term, suggesting that central banks should pursue only price stability. In other words, monetary policies must not be used to affect real activity, because a higher rate of inflation and the output and the unemployment at their natural rates will be the long-run results. So, the central banks' reputation must be of an institution tough on inflation which will not implement policies attempting to keep unemployment below its natural rate, that is, an institution that will follow rigorously the monetary rule so as to keep inflation low and stable and to increase the credibility of its policies.

4 Finite time horizon games are more reasonable than infinite, because, in the real world, every government's lifetime is finite. 
Chick (1983), however, argues against the use of the Phillips curve as a general and representative model of the economy functioning. ${ }^{5}$ The alternative Keynesian approach, here proposed, also argues against the use of the New Classical Phillips curve as the framework which may represent the general functioning of the economy and which will guide monetary policy. The criticism made by Chick, and here supported, calls our attention to the fact that assuming the New Classical Phillips curve, as a framework to explain inflation changes, means assuming a particular case in which aggregate supply finds itself, that is, a situation which legitimates higher prices caused by demand pressures because capacity utilization is full.

Sicsú (1997) - inspired on Davidson (1978, 1982), Hahn (1984) and Kregel (1984) - criticized the basic assumptions of New Classical monetary policies models. He argued that the economy does not have a natural tendency toward an equilibrium position; the equilibrium stability property would not prevail if expectations, though rational, may be heterogeneous. Hence, if expectations may be heterogeneous, they can also be disappointed and then mistakes can happen. Mistakes can change the parameters that sustain the equilibrium position suitable to the natural rate of unemployment. Consequently, the uniqueness property will not be valid either. The work of Libânio (2008) explores the idea that aggregate demand matters for economic activity, both in the short run and in the long run. To that extent, it discussed the endogeneity of the natural rate of growth, and presented two empirical exercises: (i) it accomplished tests for unit roots in output for twelve Latin American countries using panel data; the results suggested that GDP series are non-stationary and therefore shocks (both from supply and demand) may have persistent effects in the economy; (ii) it tested the hypothesis of an endogenous natural rate of growth, and the estimations suggested that the potential output has been influenced by the actual level of economic activity in Latin American economies. These results corroborate the hypothesis that aggregate demand has long-run effects in the economy, as stated by Keynes.

Recent models that consider the modus operandi of the economy based on the New Classical assumptions suggest central banks implementing and following some sort of nominal interest rate rule to control inflation (like Taylor's rule, 1993). Notwithstanding, as this rule does not consider the kind of inflation pressure, treating any kind of inflation as being caused by demand, it tends to punish output and

5 According to Chick (1983, p. 282):

To conduct a discussion of price changes with no mention of the Phillips curve might strike the reader as downright odd; since about the mid-1960s economists discussing inflation automatically reach for this tool.

There are several reasons why I have not used it. Fundamentally I do not think it was designed for this job. Secondarily I believe it was seized upon as an explanation in the belief that Keynes's model had no explanation of prices, which in turn is due to leaving out supply and profit-seeking from the IS-LM version of Keynes. 
employment at the short run and to reduce the potential of growth at the long run, therefore, in the future, leading to a situation that we call "credibility trap". 6

\section{REPUTATION AND CREDIBILITY: AN ALTERNATIVE KEYNESIAN AP- PROACH}

According to Keynes" ${ }^{7}$ and some Keynesians, in a monetary economy "fluctuations in effective demand and employment occur because, in a world in which the future is uncertain and unknown, individuals prefer to retain money, postponing consumption and investment decisions" (FERRARI; CONCEIÇÃO, 2005, p. 580). The expectations and the state of confidence of the agents play important roles for the decision-making process in an environment of "fundamental uncertainty". ${ }^{8}$ Hence, money and monetary policies also play important roles, as the agents, in conditions of uncertainty, may prefer to hold money or other liquid asset instead of acquiring goods through consumption or investment. To figure out how central banks can affect the performance of the economy through the influence of their reputation and the credibility of their policies, it is necessary to understand how economic agents take decisions based on their expectations and their state of confidence on these expectations. Therefore, it is essential to know the determining elements of expectations and confidence and how these elements are affected by central banks' reputation and credibility.

It is a consensus among economists that expectations are an important monetary policy transmission channel. In this sense, aiming at linking the reputation-credibility binomial with the process of expectations formation, the scheme presented by Dequech (1999a) is taken as a reference. The framework we propose - based on Dequech (1999a) - seeks to identify the decisive elements for the "state of expectations", emphasizing its role as a monetary transmission channel. In the scheme (figure 1), the element "knowledge" is detached as capable of affecting directly the "expectations" and indirectly the "confidence" through agents' "uncertainty perception".

6 This subject as well as the comparison between the situations of "credibility trap" and "expectation trap" will be better approached and explained in the next section.

7 According to Keynes: "money plays a part of its own and affects motives and decisions and is, in short, one of the operative factors in the situation, so that the course of events cannot be predicted, either in the long period or in the short, without a knowledge of money between the first state and the last" (KEYNES, 1973, p. 408409; emphasis added).

8 Fundamental uncertainty is defined as a situation where at least some essential information concerning future events cannot be known at the moment a decision must be taken, since this information does not exist or cannot be inferred by any existing data set. Fundamental uncertainty, as suggested by Dequech, does not mean complete ignorance about all kinds of future events that are going to happen, but refers to fundamentally relevant events for the decision-making process. For more details see Dequech (1999a, 1999b). 
As full knowledge does not exist at the moment in which a relevant economic decision must be taken, the agents make use of (i) the available information, (ii) their tacit knowledge about the living context and about the institutions able to affect them (like the central bank), and (iii) their creativity in forming prospective scenarios. Based on these elements, they form expectations that will guide their decisions in a monetary economy. As these expectations are considered an important monetary transmission channel, the monetary authority will increase its possibility of reaching its goals if the agents share the same beliefs about the future and if they are endowed with enough confidence on the expected results which are capable of affecting their personal concerns. Confidence is a fundamental component on the transmission process of monetary policies through expectations; it reflects the agents' perceptions and degree of belief concerning the disposition of the monetary authority and the way it conducts the monetary policy.

In a world where decisions are taken based on expectations regarding an uncertain future, institutions are created in order to give confidence to the public's expectations and then to enable the economic operations. ${ }^{9}$ Among the most important institutions in a monetary economy is the central bank acting through its policies; because of its capacity of exerting influence on agents' decisions through expectations, and also on real economic outcomes that both the monetary policy administration and the reputation of central banks may be considered decisive elements for the construction and stability of the "state of expectations". The central banks" reputation is a feature so important and so decisive for the process of expectations formation that Mishkin (2000, p. 9), when stressing and explaining the importance of the adoption of an explicit nominal anchor and why the U.S. government and the Fed did not commit to any explicit nominal anchor, said: "I think it is fair to say that right now the nominal anchor in the United States is Alan Greenspan".

The concept of central banks' reputation - according to the alternative Keynesian approach we propose - involves the agents' state of perception concerning (i) the preferences of the monetary authority, (ii) the actions expected to be taken by the monetary authority, and (iii) the monetary authority's character and characteristics. When this perception suddenly changes modifications may emerge in the uncertainty perceived, provoking the deterioration of the "state of expectations" of the public through the state of confidence.

Although the central banks' reputation is formed considering past events, it is capable of influencing expectations about future events. Therefore, it is expected that monetary authorities, presenting a solid and well-defined reputation of being ins-

9 According to Carvalho (1992, p. 210): "The first duty of the state in a monetary economy, in sum, can be defined as providing the information the market fails to generate". 
titutions concerned with price stability and growth, succeed in making the public's expectations converge to their predetermined goals in a faster way. Reputation and credibility serve as catalysers in the process of convergence of expectations and confidence to the policymakers' predetermined objectives. The confidence on monetary policies and on central banks is decisive for the monetary policy effectiveness through expectations.

Identifying the mechanism (or the transmission process) by which reputation and credibility affect the decisions that are going to be taken by the agents imply in knowing the elements capable of affecting the "state of expectations". Figure 1 presents how reputation and credibility exert influence over the "state of expectations" and, consequently, over agents' decisions and economic performance. The scheme shows reputation and credibility directly affecting agents' knowledge. The element 'knowledge" exerts influence upon "uncertainty perception" and upon "expectations", by the former, the way in which confidence is affected. The "state of expectations", which drives firms and banks' actions, will be decisive for prices, output and investment decisions. It must be emphasized that the uncertainty perceived, affected by the public's knowledge, may increase or decrease according (i) to central banks' reputation, (ii) to the credibility of the policy adopted, and, (iii) to the context in which central banks acts.

Figure 1 may be explained as follows: when central banks present a strong and defined reputation - compatible with the notion that monetary policies can affect both real and nominal variables - and act through credible policies which are coordinated with the other economic policies, it tends to make public's knowledge increase. As a consequence, when uncertainty perception decreases, making confidence on expectations about future profitable events increase, it creates a favorable "state of expectations" for decisions that require a longer horizon of planning (like investment decisions). The established optimistic environment provokes a reduction on liquidity preference and induces the agents to choose a portfolio with a larger amount of fixed assets - derived from investment decisions. With investments increasing, it is expected that output and income raise and unemployment decrease. 
FIGURE 1 - REPUTATION, CREDIBILITY AND THE STATE OF EXPECTATION

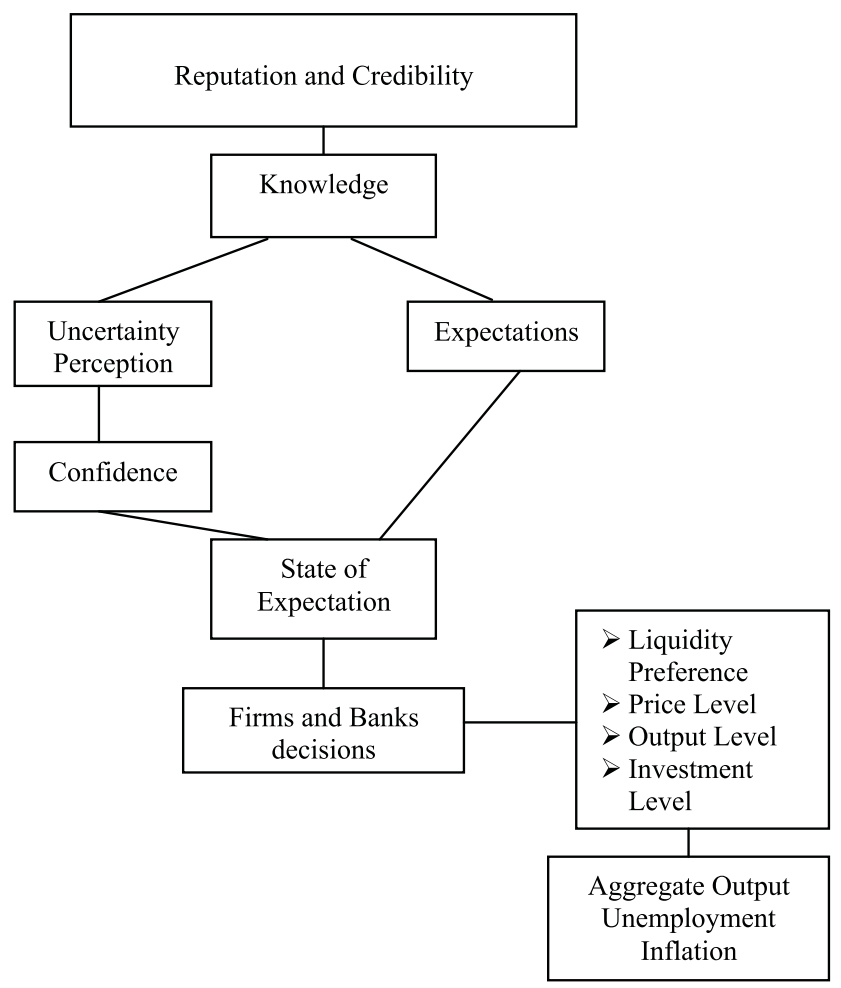

Acquiring an asset requires an appraisal about its expected profitability and its degree of liquidity. In general, as money and bonds have a higher degree of liquidity than capital assets, the investment decision will be fundamentally influenced by expectations about the future profitability offered by different kinds of assets. Central banks aiming at increasing the potential economic growth must induce the agents to change financial assets for capital goods (assets), that is, to change interest gains for expectations of promising future profits.

Monetary authorities must be also capable of establishing a stable price environment which will reflect itself on the public's expectations regarding the central banks' commitment to keeping inflation low and stable. If the private sector believes (expects) that the goals for inflation and growth are going to be reached and when central banks revealed their commitment to both and have been coordinating their policies with the other economic policies, doing whatever is necessary and coherent for that to happen, hence the private sector will consider these beliefs when deciding and will readjust prices and form expectations for inflation and demand growth based on these informations. 
As central banks present a strong and defined reputation and act implementing credible and coordinated policies aiming at promoting inflation stability and economic growth, their ability to influence the "state of expectations" towards more investment decisions are improved. Inversely, central banks presenting a weak reputation, in a context of uncertainty and assuming the New Classical recommendations make the agents' liquidity preference increase, because they find difficulties to keep interest rate variability low.

When assuming the idea that monetary policy is not neutral in either the short or the long terms and recognizing that the public not only forms expectations for inflation, but also for future events that may affect its business' profitability, central banks can be effective in changing both real and nominal variables. With the idea that monetary policy is not neutral, it is conferred to central banks a wider filed of action than the one proposed by the New Classical approach. The way central banks conduct their policies, choose their instruments and coordinate their policies with the other policies, besides providing information for the process of expectations formation, add knowledge on how they understand the operation of the economy. As Carvalho (1992, p. 209-210) once wrote:

There will be different instruments for each of the goals and the general
objective is to allow private agents to decide in more safety and with bet-
ter knowledge of factual possibilities. The state can see further because it
can influence the economy. It has to use this influence to make explicit
to agents how the environment is likely to evolve in the relevant future,
within which private allocative decisions are to be made.

Different sorts of policies (or combination of policies) as well as different sorts of reputations may lead to distinct equilibrium positions - provided that several unlike "states of expectations" are established - which will enable authorities to reach different outcomes in terms of social welfare. According to Keynes (1973, p. 55) "there is no unique long-period position of equilibrium equally valid regardless of the character of the policy of the monetary authority. On the contrary there are a number of such positions corresponding to different policies", that is, there are several equilibrium positions in the economy associated with different kinds of implemented monetary policies.

For a monetary policy to be considered credible, it must be considered efficient. According to Sicsú (2001), an efficient monetary policy would be one that (i) aims at unambiguous goals, (ii) leaves the least room for its tools to be used in contradiction with each other, or with other policy tools, (iii) makes use of tools suitable for its goals, (iv) gives out clear signals to agents and financial markets in order to stimulate them to act in the same directions desired by the policymakers, and (v) is 
able to reach a specific goal without harming the economic performance as a whole. In this way, an efficient monetary policy, and thus credible, must be performed by an institution competent on reducing uncertainties, coordinating expectations and following unlike but feasible objectives - and not only low and stable inflation, though this is a very important objective.

The debate concerning how the monetary policy should be conducted and what in fact are its effects on the economy has always been the core of the "rules rather than discretion" literature, which in turn, is supported by another discussion: whether the monetary policy neutrality in both the short and the long terms is valid or not. In general, those who defend the neutrality argue in favor of the need of using some strict rule-based policy to guarantee (i) the application of dynamically consistent actions, (ii) the avoidance of the inflation bias and, as a consequence, (iii) the reaching of the main central bank objective which is stable and low inflation - according to the New Classical economics.

The orthodox approach defends the conduction of the monetary policy through a rigid reaction rule, where the nominal interest rate is changed whenever the observed inflation and/or the inflation expectations deviate from the (implicit or explicit) inflation target or if the output gap changes, becoming the responsible for demand pressures over prices. Although nominal interest rate manipulations can reduce inflation, such a policy can also result on changes in the degree of liquidity of the economy, with effects upon investment financing plans and upon liquidity preference, bringing impacts on the investment decisions and on the real economy. Constant manipulations as well as the great variability on the interest rate, aiming at controlling inflation, end up producing an unfavorable environment for investments, due to uncertainties and to liquidity preference increases. Thus, if low levels of investment occur for long periods - explained by high liquidity preference and high interest rate variability - they will end up reducing potential economic growth. This reduction on potential growth makes the output gap quickly compress whenever short periods of economic warming are observed, provoking a monetary policy reaction - through interest rate - that jeopardize even more this potential economic growth.

In fact, how fast central banks succeed in forming a low and stable price environment - which helps reducing inflation variability and interest rate variability - the quicker the ideal necessary conditions for the desired process of economic growth will be created. However, the use of a strict monetary policy rule - through interest rate manipulations - though capable of reducing and stabilizing the observed inflation as much as the inflation expectations, in a situation of high idle capacity and considering that monetary policy can affect output and employment; it may lead the 
economy to present low (and constant) economic growth rates below those socially desirable, as much as it creates an adverse environment for investment decisions.

At this point, it is important to stress that, in the post-keynesian approach, there are many and different causes for inflation, and, hence, there are several types of inflation (see for example, DAVIDSON, 1994; SICSÚ, 2003). According to this view, the following types of inflation may be classified: (i) wage inflation, (ii) profit or degree of monopoly inflation, (iii) imported inflation, (iv) demand inflation, (v) inflation of decreasing returns to scale, (vi) tax inflation, and, (vii) inflationary shocks (such as, spot and commodity inflation). Since different types of inflation are recognized, consequently, for each type of inflation, a specific antiinflationary tool should be used. For instance, the cases of wage and profits/degree of monopoly inflation should be fight through the strategy of tax-based on incomes policy; ${ }^{10}$ regarding imported inflation, a combination of exchange-rate, monetary, tax and industrial policies could be used; tax inflation should be avoided by governments themselves through fiscal policies committed with macroeconomic stability as a whole, and not jut with price stability; demand inflation, according to post-keynesians, should be fight through contractionary macroeconomic policies, mainly through reductions on government spending. ${ }^{11}$ The post-keynesian proposal represents much more than an antiinflationary macroeconomic policy. It must be faced as a permanent program against inflation which covers structural reforms, the construction of institutions and the use of specific tools of economic policy.

The keynesian approach, here developed, suggests that full employment as well as inflation stability policies should be implemented by the combination and coordination of three types of instruments: monetary policies, fiscal policies and income policies. As stressed by Carvalho (1992, p. 214): "This combination of the three legs of economic policy would allow the adequate macroeconomic management that would maintain full employment and price stability". In order to establish the role of each economic policy, according to the post-keynesian approach, emphasizing the importance of being conducted through coordinated actions aiming at stimulating both economic growth and price stability, Carvalho (1992, p. 216) suggested that:

Fiscal Policy was destined to sustain long-term expectations as to the aggregate level of income the state was committed to support. Income policies would regulate the wage/price relation to avoid cost inflation. The role of monetary policy, under these conditions, would be to provide

10 This type of policy was developed by Weintraub and Wallich (1978) and it was incorporated by the post-keynesian approach.

11 For more details concerning the classification of the different types of inflation as well as the specific antiinflationary tool and/or strategy that should be implemented, see, for example, Sicsú (2003) and Carvalho (1992). 
active balances for transaction needs and to prevent increases in liquidity preference from being translated into higher interest rates that could threaten investment. These policies should be jointly implemented. None of them can be thought of as Keynesian when taken in isolation because they would create difficulties for the economy that could end up in a crisis.

In this sense, the definition and design of policies should consider the following principles: (i) institutions should be created to achieve more efficient and permanent coordination of agents, allowing them to develop coherent strategies; (ii) a set of instruments must be developed, paying particular attention to the timing of their operation, and; (iii) specific policies should be chosen not is isolation but as parts of a global plan to control and to steer the economy (these should not be fiscal policies decided independently of monetary policies or of any other). ${ }^{12}$

Thus, the alternative approach suggests that a mechanical rule-based policy for fighting inflation - through constant interest rate manipulations whenever inflation and inflation expectations deviate from the target - besides harmful since liquidity preference is increased creating a pessimist "state of expectations" for investments, it practically ignores the other sources of the inflationary process and it is not practical (as explained by SARDONI; WRAY, 2006) neither compatible with the real functioning of the economy. The persistent use of such a rule and the kind of reputation built by the monetary authority - of being an institution concerned exclusively with inflation - may become a threat for future monetary policy actions and its effectiveness, creating what we call a "credibility trap". Moreover, according to Svensson (1999, p. 13)

a commitment to an instrument rule does not leave any room for judgmental adjustments and extra-model informations", that is, this kind of "commitment leaves no room for revisions of the instrument rule, when new information and research results in revisions of the model.

An efficient and credible monetary policy must not be only the one which is considered capable of providing an environment of low and stable inflation. Since the monetary policy can also affect the real side of the economy, its constant and exclusive use as an instrument to fight inflation may lead to effectiveness (and then, credibility) loss whenever necessary to improve the economic performance or to contain a monetary-financial crisis, through expectations channel.

12 Regarding this subject and how policy instruments should be implemented, see Carvalho (1992). 
Our approach suggests that central banks which work with the assumption of monetary policy neutrality (at short and long terms) and act guided by and committed to a strict interest rate reaction rule which leaves no space for discretion - ignoring its long run effects on output and employment - tend to bring up the following reputation: whenever inflation and inflation expectations - no matter the source - deviate from the target, the public expects that central banks will act through interest rate manipulations, inducing the agents, as a consequence, to form inflation expectations converging to the target. Nevertheless, this kind of attitude will also create (at the same time) the reputation of being an institution free from employment, output and income responsibilities, which in turn, induce the agents to form pessimist expectations concerning the monetary policy effectiveness to affect the economy as a whole, even when necessary. The central banks' reputation proposed by the New Classical approach and the use of the interest rate reaction rule, in fact, may turn the policy into an efficient action in terms of inflation decreasing, though at the costs of an aggregate demand compression which sometimes may not have been the source of the inflation pressure.

Recently, economists have been discussing whether the use of a rigid interest rate rule to exclusively control inflation is really a valid option and at the same time whether the reputation developed by central banks of being institutions exclusively concerned about inflation represents another valid option. The alternative Keynesian approach proposed argues that both the adopted rule and the developed reputation which follows New Classical principles exempt central banks of their duties and may create a situation of "credibility trap", where the monetary policy effectiveness as a whole is lost.

One of the main contributions of our approach for the debate regarding the monetary policy effectiveness and how the monetary policy should be conducted is the presentation of another understanding about what a credible monetary policy is, and what kind of reputation the monetary authority should build, provided that: (1) monetary policy is not neutral, being capable of affecting both nominal and real variables, and; (2) the inflationary process presents different sources, being initiated not only by demand pressures. It is proposed, following Kozicki (1999), that the use of a rigid interest rate rule is limited and its reliability is questionable as it disregards the sources of inflation and firms' strategies concerning price-making process.

Therein, the matters involving reputation, credibility and monetary policy effectiveness ought to regard distinct perspectives besides that one proposed by the New Classical approach. Considering that the monetary policy can reach several objectives (such as inflation, output and employment) and considering that capitalism system is intrinsically unstable needing casual interventions by central banks, then, the follow- 
ing question can be raised: why build the reputation of being an institution seeking only one objective (as inflation), whether other macroeconomic variables may be affected - and in fact are, positively or negatively - and whether central banks are often convoked to account for economic performance as a whole and not only for inflation performance? Actually, central banks which act through rigid policy rules, seeking only one objective and developing the sort of reputation in agreement with the New Classical approach, may end up running out of degrees of freedom and credibility to solve other urgencies when necessary, due to previous "sub-utilization" of its monetary instruments. This loss of degrees of freedom to solve other problems as well as to help achieving other objectives represents the situation of "credibility trap" faced by central banks and their policies. This situation may be recognized when monetary policies lose power to affect the economy as a whole through the "expectation transmission channel". ${ }^{3}$

Our approach suggests that the monetary authority's reputation must not be related to the perception that the monetary policy should not or cannot be altered through discretionary actions or it should be used for the search of only one kind of objective, but to the fact that its implementation must be appropriate for a specific conjuncture. Indeed, central banks and their policies should have the credibility to operate the right interventions whenever necessary, in favor of economic growth and employment as well as inflation stability.

Reputation must be understood as a complementary element which acts on the propagation process of the monetary policy for the economy through the expectation channel, since it constitutes a key piece of corporate culture that determines how the public is expected to react from monetary policy actions, that is, reputation may be understood as an "implicit contract or anchor" that outlines the expectations of the public. Whenever central banks define and strengthen the reputation of being an institution concerned with matters related to economic growth and employment as well as inflation, the knowledge of private agents and then their expectations regarding central banks' performance will incorporate this notion. Therein, when central

13 The situation of "credibility trap" must not be seen as similar to the situation of "expectation trap" presented by Chari, Christiano and Eichenbaum (1998). The "expectation trap", suggested by them, emerges when the monetary authority cannot commit to future policies, meaning that discretion exposes the economy to this sort of trap. Following the traditional approach presented by Kydland and Prescott (1977), Barro and Gordon (1983b), Backus and Driffill (1985a, 1985b) they argued that, under discretion, policymakers can be pushed into pursuing inflationary policies. This could happen when the private sector, for whatever reason, expects high inflation. Hence, under these circumstances, the monetary authority may find it optimal to accommodate private agents' expectations if the cost of not doing so is a recession. When the monetary authority does accommodate, private agents' expectations are self-fulfilling. They refer to such a situation as one in which the economy has fallen into an expectation trap. In this way, they suggested that limited commitment could eliminate expectation traps by forcing the monetary authorities to commit before private agents make their decisions. For more details about the assumptions that sustain the model which considers the situation of "expectation trap", see Chari, Christiano and Eichenbaum (1998). 
banks announce their intentions, the agents will easily understand the signs issued and will form expectations according to the aimed objectives by the institution.

As mentioned by Mishkin (2000, p. 3): "the public cares about output as well as inflation fluctuations, and so the objectives for a central bank in the context of a long-run strategy should not only include minimizing inflation fluctuations but should also include minimizing output fluctuations". Hence, the adoption of a "flexible inflation forecast targeting” strategy besides being perfectly compatible with the notions presented in this section it represents a strategy where central banks are also concerned with the stability of output and/or the exchange rate. Under this strategy, as central banks concern about output and other variables, when inflation deviates from its target they will attempt to take inflation back to the target at a more gradual pace. Real world central banks are moving toward this strategy or to some extent since it represents a possible monetary strategy that conciliates commitment to an explicit objective and the possibility of giving attention to economic activity. Flexible inflation forecast targeting can also help reducing uncertainties surrounding the economy since it requires commitment, transparency and accountability from central banks, makes the policy easy to understand, helps to build a consensus of expectations, as can also play a useful role as an immediate policy objective and a criterion of performance.

In democratic societies, the citizens elect their representatives expecting that the government will follow and accomplish not just one objective but the amount of objectives that will bring up the best results in terms of social welfare - it means economic growth, stable and low inflation, unemployment reduction and less social inequalities. As inflation performance represents just one of the things that the public take into account when choosing their candidates and as monetary policies are able to affect real and nominal variables, it is not worth conferring full independency for the monetary authority to act seeking only one goal through a rule that can jeopardize other objectives - in fact, there is wide agreement that central banks should be goal dependent and instrument independent. So, it is also not worth developing a reputation that can jeopardize the effectiveness of monetary policy as a whole by sub-utilizing it.

As suggested by Montes (2007) and Lima and Setterfield (2008a), the adoption of targets for both inflation and output aims at anchoring the expectations of the public. ${ }^{14}$ Both works examine the compatibility of inflation targeting with a monetary economy. The results suggest that policymakers can both set and achieve an inflation

14 The work of Lima and Setterfield (2008a) concludes - as a key result - that orthodox policy regimes do not provide appropriate policy mixes; the more orthodox the policy regime becomes, the less viable is inflation targeting considering a monetary economy. 
target without adverse consequences in terms of output and employment, as long as an appropriate policy mix is chosen. When both monetary and non-monetary policies are implemented, meaning that central banks policies are coordinated with other government policies, in order to improve the macroeconomic performance as a whole, the chances of occurrence of the "credibility trap" are considerably reduced.

\section{FINAL CONSIDERATIONS}

According to the alternative Keynesian approach, for central banks improve their capacity to affect the "state of expectations" of the agents, and then, through monetary interventions succeed in reaching their predetermined goals as fast as possible and with more effectiveness, they must define and strengthen their reputation and implement efficient and credible policies, without neglecting their capacity and responsibility to improve the economy as a whole - it means that output and employment must not be set apart.

Undoubtedly, monetary policy exerts influence on inflation through interest rate manipulations provided that it affects aggregate demand. However, the inflationary process is not always associated with a demand warming, what requires other sorts of economic policies interventions. By reducing the way of dealing with inflation to a unique instrument and by assigning to central banks the exclusive commitment to price stability, other aspects of economic life which have the power to compromise the potential of economic growth at long term may be affected.

One of the arguments, presented by the New Classical economics, for the adoption of a rule for the monetary policy (like an interest rate rule) is its effects upon expectations of inflation and then upon the observed inflation. Those who defend the conduction of the monetary policy through a rigid rule judge the success of the policy based exclusively on inflation performance, that is, based on the deviations of the inflation or the expectations of inflation in relation to the target. They attribute almost zero weight for real activity performance or any other possible economic objective. These results are not taken by the parameters and/or statistics that appraise the success of monetary policy and its credibility.

The rule-based policy for fight inflation through interest rate manipulations makes no distinction between the firms and/or the markets that are really responsible for the process of inflation and those that are not. As a consequence, many firms which are acting compatible with price stability will be punished when interest rate is raised. Some of these firms may not resist high financial costs and the weak de- 
mand, starting a process of bankruptcy that will result in a higher unemployment rate. Other firms may give up from realizing the investments that will be necessary to absorb the workers still unemployed. So, when it is recognized that the beginning of an inflationary process may not always be attributed to an increase in demand, it gives rise to the need of issuing a precise inflationary diagnosis which will be conclusive for the choice of the instrument or for the combination of instruments that will help reducing and stabilizing the inflationary process.

When central banks act through a strict mechanical interest rate rule concerned with only one objective, that is, aiming at maintaining inflation low and stable, it disregards: 1) the process of price formation as a result from distributive conflict between groups and agents with specific goals, meaning that the rule affects distinct economic groups with different insertions in a different way; 2) the different impacts on firms presenting different cost structures, resulting on particular sorts of reactions from the firms, and; 3 ) the consequences for the process of fund accumulation. Therefore, this kind of policy is not recommended for this purpose as well as the development of a reputation following the New Classical standards, since they do not allow the creation of a favorable environment for the process of economic growth. In fact, they create a situation of "credibility trap" for central banks, making it unfeasible - through expectations channel - for central banks to improve the economic performance as a whole; because to keep this (New Classical) reputation monetary authorities must follow the rule which jeopardize the economic growth.

Thus, the alternative Keynesian approach considers that a successful monetary policy must take into account (i) the acquired economic growth, (ii) the obtained inflation' stability, (iii) the installed capacity used level, (iv) the promoted income distribution, and (v) the acquired monetary-financial system stability. Therein, central banks must regard the impacts of their policies upon the process of pricing and their consequences for the internal fund accumulation, as well as upon liquidity preference and the investment decisions.

Although the inflationary process is usually and strictly treated as a problem liable to theoretical explanation at the macroeconomic level, its understanding requires a wider acknowledgment of the firms' process of price formation. Hence, a previous microeconomic approach makes itself necessary, though it is not a sufficient condition to elaborate a theoretical analysis regarding the inflationary process and how it should be opposed whenever situated on an unwished level. That is, to understand theoretically the inflationary process and its dynamics as well as to recommend poli- 
cies which will fight this process an integrated analysis involving micro and macro knowledge is required. ${ }^{15}$

\section{REFERENCES}

ANDERSEN, T. M. Credibility of policy announcements - the output and inflation costs of desinflationary policies. European Economic Review, v. 33, n. 1, Jan. 1989.

BACKUS, D.; DRIFFILL, J. Inflation and Reputation. The American Economic Review, v. 75, p. 530-38, 1985a.

. Rational expectations and policy credibility following a change in regime. Review of Economic Studies, v. 52, n. 2, 1985 b.

BARRO, R. J. Reputation in a model of monetary policy with incomplete information. Journal of Monetary Economics, v. 17, p. 3-20, 1986.

; GORDON, D. B. A positive theory of monetary policy in a natural rate model. Journal of Political Economy, v. 91, n. 41, 1983a.

. Rules, discretion and reputation in a model of monetary policy. Journal of Monetary Economics, v. 12, n.1, p. 101-122, 1983 b.

BLACKBURN, K.; CHRISTENSEN, M. Monetary policy and policy credibility: theories and evidence. Journal of Economic Literature, v. 27, n.1, Mar. 1989.

BLANCHARD, O. J. Credibility, disinflation and gradualism.. Economic Letters, v. 17, n.3, 1985.

CARVALHO, F. C. Mr. Keynes and the Post Keynesians: principles of macroeconomics for a monetary production economy. Edward Elgar Publishing, 1992.

CHARI, V. V.; CHRISTIANO, L. J.; EICHENBAUM, M. Expectation traps and discretion. Journal of Economic Theory, v. 81, issue 2, p. 462-492, Aug. 1998.

CHICK, V. Macroeconomics after Keynes: a reconsideration of The General Theory. Phillip Allan Publishers Limited, 1983.

CUKIERMAN, A. Central Bank Behavior and Credibility - some recent developments. Federal Reserve Bank of St. Louis, 1985.

. Central Bank strategy, credibility, and independence: theory and evidence. Cambridge, Mass.: The MIT Press, 1992.

15 Making use of an alternative approach, the recent work of Lima and Setterfield (2008b) examined the empirical and theoretical status of the cost-push channel of monetary policy, according to which interest rates affect the costs of production and hence pricing behavior. It is shown that different variants of cost-plus pricing behaviour give rise to qualitatively different specifications of the cost-push channel, with important consequences for macrodynamics and the conduct of monetary policy. 
; MELTZER, A. H. The Credibility of monetary Announcements. In: NEUMAN, Manfred J. M. (Ed.). Monetary Policy and Uncertainty. NY: Duncker and Humbolt, 1986.

DAVIDSON, P. Money and the real world. New York: Macmillan, 1978. 1982.

International money and the real world. New York: John Wiley \& Sons, . Post Keynesian macroeconomic theory. Cheltenhan: Edward Elgar, 1994.

DEBELLE, G.; FISCHER, S. How independent should a Central Bank be? In: Fuhrer, J. (Ed.). Goals, Guidelines, and constraints facing monetary policymakers. Federal Reserve Bank of Boston, Boston, 1994.

DEQUECH, D. Expectations and confidence under uncertainty. Journal of Post Keynesian Economics, v. 21, n. 3, Spring 1999a.

. Uncertainty, conventions and short-term expectations. Brazilian Journal of Political Economy, v. 19, n. 3 (75), July-Sept. 1999b.

DRAZEN, A. Political economy in macroeconomics. Princeton University Press, 2000 .

FELLNER, W. J. Towards a reconstruction of macroeconomics: problems of theory and policy. American Enterprise Institute, 1976.

. The credibility effect and rational expectations: implications of the Gramlich study. Washington, Brookings Papers on Economic Activity, n. 1, p. 167-190, 1979.

FERRARI, F; CONCEIÇÃO, O. A. C. The concept of uncertainty in Post Keynesian Theory and in institutional economics. Journal of Economic Issues, v. 39, n. 3, Sept. 2005.

FRIEDMAN, M. The role of monetary policy. The American Economic Review, v. $58,1968$.

. The optimum quantity of money, and other essays. Chicago, IL: Aldine Pub. Co. 1969.

GOODFRIEND, M. Monetary policy in the new neoclassical synthesis: a primer. Federal Reserve Bank of Richmond Economic Quarterly, v. 90/3, Summer 2004.

; KING, R. G. The new neoclassical synthesis and the role of monetary policy. In: BERNANKE, Ben; ROTEMBERG, Julio (Ed.). NBER Macroeconomics Annual 1997. Cambridge, Ma: MIT Press, 1997.

HAHN, F. Equilibrium and macroeconomics. Oxford: Basil Blackwell, 1984.

KEYNES, J. M. The general theory of employment, interest and money. London: Macmillan Press, 1936.

. The collected writings of J. M. Keynes. London: Macmillan, 1973. 
KING, R. G. The new IS-LM model: language, logic, and limits. Federal Reserve Bank of Richmond Economic Quarterly, vol. 86/3, Summer 2000.

KOZICKI, S. How useful are Taylor rules for monetary policy? Economic Review, Federal Reserve Bank of Kansas City, second quarter, 1999.

KREGEL, J. A. Constraints on the expansion of output and employment: real or monetary?. Journal of Post Keynesian Economics, v. 7, n. 2, winter 1984-1985.

KYDLAND, F. E.; PRESCOTT, E. C. Rules rather than discretion: the inconsistency of optimal plans. Journal of Political Economic, v. 85, n. 3, 1977.

LIBÂNIO, G. Aggregate demand and the endogeneity of the natural rate of growth: evidence from Latin American economies. I Encontro Internacional da Associação Keynesiana Brasileira, UNICAMP-Campinas, abr. 2008.

LIMA, G. T.; SETTERFIELD, M. Inflation targeting and macroeconomic stability in a Post Keynesian economy. Journal of Post Keynesian Economics, v. 30, n. 3, Spring 2008a.

. Pricing behaviour and the cost-push channel of monetary policy. I Encontro Internacional da Associação Keynesiana Brasileira, UNICAMP-Campinas, abr. $2008 b$.

LOHMAN, S. Optimal commitment in monetary policy: credibility versus flexibility. The American Economic Review, v. 82, 1992.

LUCAS, R. E. Jr. Expectations and the neutrality of money. Journal of Economics Theory, v. 4, April 1972a.

Econometric testing of the natural rate hypothesis. In: ECKSTEIN, Otto (Ed.). The econometrics of price determination. Washington: Board of Governors of the Federal Reserve System, 1972 b.

. Some international evidence on output-inflation tradeoffs. The American Economic Review, June 1973.

MISHKIN, F. S. What should Central Banks do?. Federal Reserve Bank of St. Louis Review, November/December 2000.

MONTES, G. C. Política monetária, inflação e crescimento econômico: a influência da reputação da autoridade monetária sobre a economia. XXXV Encontro Nacional de Economia ANPEC, Recife - PE, 2007.

MUTH, J. F. Rational expectations and the theory of price movement". Econometrica, v. 29 , n.3, July 1961.

PERSSON, T.; TABELLINI, G. Monetary and fiscal policy. Cambridge, Mass.: The MIT Press, 1994.

ROGOFF, K. The optimal degree of commitment to an intermediate monetary target. The Quarterly Journal of Economics, v. 100, Nov. 1985.

. Reputational constraints on monetary policy. Carnegie-Rochester Conf. Ser. Public Policy, 26, Spring 1987. 
ROMER, D. Keynesian macroeconomics without the LM curve. Journal of Economic Perspectives, v. 14, n. 2, Spring 2000.

SARDONI, C.; WRAY, L. R. Monetary policy strategies of the European Central Bank and the Federal Reserve Bank of the United States. Journal of Post Keynesian Economics, v. 28, n. 3, Spring 2006.

SARGENT, T. J. Rational expectations, the real rate of interest, and the natural rate of unemployment. Brooking Papers on Economic Activity, 1973.

SARGENT, T. J.; WALLACE, N. Rational expectations, the optimal monetary instrument, and the optimal money supply rule. Journal of Political Economy, 83, Apr. 1975.

. Some Unpleasant monetarist Arithmetic. Federal Reserve Bank of Minneapolis Quarterly Review, p. 1-17, Fall 1981.

SICSÚ, J. A negação da ineficácia da política monetária: a alternativa de Keynes e dos pós-keynesianos. Análise Econômica, ano 15, n. 28, p. 80-107, set. 1997.

. Credible monetary policy: a Post Keynesian approach. Journal of Post Keynesian Economics, v. 23, n. 4, Summer 2001.

. Políticas não monetárias de controle da inflação: uma proposta pós-keynesiana. Análise Econômica, v. 21, n. 1, 2003.

SVENSSON, L. Optimal inflation targets, "conservative" Central Banks, and linear inflation contracts. The American Economic Review, v. 87, n. 1, Mar. 1997.

. How should monetary policy be conducted in an era of price stability? NBER Working Paper, October 1999.

TAYLOR, J. Discretion versus policy rules in practice. Carneige-Rochester Conference on Public Policy. 39, p. 195-214, 1993.

. Teaching modern macroeconomics at the principles level. The American Economic Review, v. 90, n. 2, 2000.

WALSH, C. Optimal contracts for central bankers. The American Economic Review, v. 85, n.1, Mar. 1995.

WEINTRAUB, S; WALLICH, H. A tax-based incomes policy. In: WEINTRAUB, S. (Org.). Keynes, keynesians and monetarists. Philadelphia: University of Pennsylvania Press, 1978.

WOODFORD, M. Interest and prices: foundations of a theory of monetary policy.

Princeton: Princeton University Press, 2003. 